ICH 2019

International Conference on Humanities

\title{
SHOREBIRD ABUNDANCE AND SPECIES RICHNESS IN PENANG ISLAND
}

\author{
Nur Asnida A Razak (a), Azimah Abd Rahman (b)* \\ *Corresponding author
}

(a) School of Biological Sciences, Universiti Sains Malaysia, Penang, Malaysia, asnida2405@gmail.com (b) School of Humanities, Universiti Sains Malaysia, Penang, Malaysia, azimahrahman@usm.my

\begin{abstract}
Mangroves area is one type of landscape in Malaysia that sustains various species of shorebirds. Throughout the years, several species of shorebirds are experiencing tremendous declination in population size. Therefore, the species are classified as endangered and near-threatened under the IUCN Red List of Threatened Species. Development of coastal wetlands for industrial needs and human disturbances are two major factors affecting the number of the migrating species. This study focused on the abundance and species richness of shorebirds at two main sites i.e. Teluk Air Tawar and Kuala Muda. The birds were observed and counted using a point count method from November 2017 to January 2018. Abiotic factors included temperature, humidity, and light intensity was also studied. A total of 3293 birds, belonging to four families were recorded i.e. Scolopacidae, Ardeidae, Charadriidae, and Laridae. Among these, the family Scolopacidae was the most abundant which accounted for $85 \%$ of the total birds at Teluk Air Tawar and $61 \%$ at Kota Kuala Muda. The family Laridae was least abundant family at both sites with the percentage of $1 \%$ at Teluk Air and 5\% at Kota Kuala Muda. Research findings showed that Teluk Air Tawar was an ideal habitat for several shorebirds due to the bigger mangrove estuary than Kota Kuala Muda. It functions as a breeding site for aquatic organisms as well as providing shelter for various bird species including shorebirds. Therefore, conservation efforts should be implemented to continuously preserve and protect the mangrove areas to benefit both human and wildlife populations.
\end{abstract}

2357-1330 (C) 2020 Published by European Publisher.

Keywords: Shorebirds, mangrove, species abundance, species richness. 


\section{Introduction}

Shorebirds are group of small to medium size wading birds with variety of bill shapes. The most dominant bird species includes; waders, herons, egrets, storks and birds of prey such as; sea eagles Haliaeetus leucogaster, brahminy kites Haliastur indus, ospreys or seahawk Pandion haliaetus and greyheaded fish eagle Ichthyophaga ichthyaetus. Kingfishers and bee-eaters are among the most colourful birds commonly observed in mangroves (Saenger et al., 1983). Each bio-geographical region in the world supports 150 to 250 bird species and in Peninsular Malaysia about 166 species of birds have been documented, out of which 48 species are migratory and 118 native (Zakaria \& Rajpar, 2010). Many shorebirds are migratory and undertake long route of migration up to $12,000 \mathrm{~km}$ from their breeding grounds to wintering areas. They are usually gregarious and wetland inhabitant where they feed and breed.

Wetland or mangrove area are full of heterogeneous food resources and haven for wide variety of water birds (especially shorebirds) and terrestrial birds. Mudflats area are fringe sedimentary intertidal habitats consist of silts and clays with high organic content which become a feeding grounds for resident and migrant birds species due to abundance of small fishes, crustaceans and molluscs (Dahdouh-Guebas et al., 2000; Kokwaro, 1985; Robertson \& Massenbauer, 2005). As reported, the mudflats area in Pulau Pinang covers approximately 1,777 ha (3.57\%) of total state's area (Rajpar \& Zakaria, 2014). The migratory birds utilize the large mudflat area for feeding and resting during their migratory route from the northern to the southern hemisphere and some of them over wintering for breeding (Jasmi, 1983).

Shorebirds species show distinctive habitat preferences and display variety of adaptations to exploit the wetland resources. Habitat selection in birds may greatly vary from species to species, depending upon the morphology of the bill (i.e. straight, elongated, slender, curved bills), prey availability (i.e. richness, and vulnerability to capture) and foraging behaviour such as visual vs. tactile foragers (Zakaria \& Rajpar, 2010). Mudflat area especially in mangrove forest is the most rich and diverse habitat on earth (Sandilyan \& Kathiresan, 2012). The complex structures of mangrove forests supports high density and diversity of bird species through offering extensive and excellent feeding grounds of mudflats and roosting sites for resident as well as migratory species (MacArthur, 1964).

\section{Problem Statement}

Malaysia has about 12 international important sites for the migration of shorebird including Teluk Air Tawar- Kuala Muda coast. Shorebird can be seen in Malaysia coast especially during October until December every year. They will arrive in these three months to find for food, shelter before they fly back to their origin starting January in the next year. Based on the report by Wetlands International, maximum counts of species at Kuala Kedah to Kuala Sungai in Malaysia are Lesser Sand Plover, Terek Sandpiper, Broad-billed Sandpiper and Marsh Sandpiper (Bamford et al., 2008). True shore bird show adaptation especially at their bill for probing mud and sand for invertebrates living in the shore soil at different depth (Webb et al., 1979)

Within East Asian-Australian Flyway (EAAF), 54 migratory shorebirds are identified (15 restricted to EAAF) (34 species with data, 20 species inadequate and no estimates provided). About 8 million migratory shorebirds moving through EAAF, from the 'rarest' species (spotted greenshank Tringa guttifer) 
to the 'most common' species (oriental pratincole) (Bamford et al., 2008). However, EAAF still the least known wader population trends flyway in the world (Atkinson et al., 2006).

Asia Pacific Migratory Waterbird Conservation Strategy 1996-2000 was developed during 1994 to achieve long term conservation for shorebird and habitats in Asia Pacific through establishment of networks of managed sites of international importance for migratory shorebird (Watkins \& Mundkur, 1997). Within East Asian-Australian Flyway (EAAF), a decline 22.4\% between 1983-1986 and 2004-2006 had showed at the coast of Selangor and Sarawak (Wei \& Ounsted, 2007)

According to book United States Shorebird Conservation Plan, in the plan of conserving shorebird, there is a few challenges faced. For instance, long distance migration and cause the effort of protection for critical sites must be coordinated over vast distances often involving many different countries. Next, low reproductive potential, concentration (makes them vulnerable to environmental disruption because much of the population is in the same place at the same time) and population change in shorebird for example large habitat losses and significant declines in shorebird population (Kendall et al., 2011).

Bird-abundance monitoring program was run by many organizations to make sure its abundance is in good level. Jonathan Bart believe this program will be develop in the next five to ten years with the integration of bird abundance monitoring with demographic monitoring programs and with ecological monitoring (Bart, 2005).

\section{Research Questions}

1.How the pattern distribution and population of shorebirds at Teluk Air Tawar-Kuala Muda coast 2.How Geographical Information System (GIS) can be used in pattern distribution analysis of shorebirds

3. What the threats, habitat requirements and feeding ecology of shorebird at Teluk Air Tawar-Kuala Muda coast.

\section{Purpose of the Study}

Main purpose of this research is to study the pattern distribution of shorebird in Teluk Air TawarKuala Muda coast. As known, some of shorebird species are list as endangered species. This is cause by the development of the place and the disturbance made affect the shorebirds. They are very easily disturbed by close activity. When shorebirds are disturbed, they waste hard-earned energy reserves, reducing their ability to survive on their long migration. Disturbance is any action that interrupts the breeding, feeding or resting of shorebirds. So, by doing this research, idea to slow down the development of Teluk Air TawarKuala Muda coast can be suggested through the evidence of data collected.

Furthermore, using GIS application can make precise mapping compare to the previous data collection that using manual way to map it. It also can save time by just using GIS application and SPSS to analyse the data. This research contributes bigger understanding about the relationship between the shorebird species and the surrounding area that depend one another in their ecosystem. The shorebird eventually will control the population of marine species and make the relationship in the ecosystem stable. 


\section{Research Methods}

\subsection{Study Area}

The study has been conducted at Teluk Air Tawar, Seberang Perai and Kuala Muda, Kedah. Teluk Air Tawar located at latitude $5^{\circ} 28^{\prime} 0^{\prime} \mathrm{N}$ and longitude $100^{\circ} 23^{\prime} 0^{\prime} \mathrm{E}$ which is a small town north of Butterworth in North Seberang Perai district and south of the Kepala Batas district in Penang, Malaysia. Whereas, Kuala Muda is located at latitude $5^{\circ} 35^{\prime} 0^{\prime} \mathrm{N}$ and longitude $100^{\circ} 22^{\prime} 58^{\prime} \mathrm{E}$. Teluk Air Tawar means "freshwater bay" in the Malay language (Figure 01).

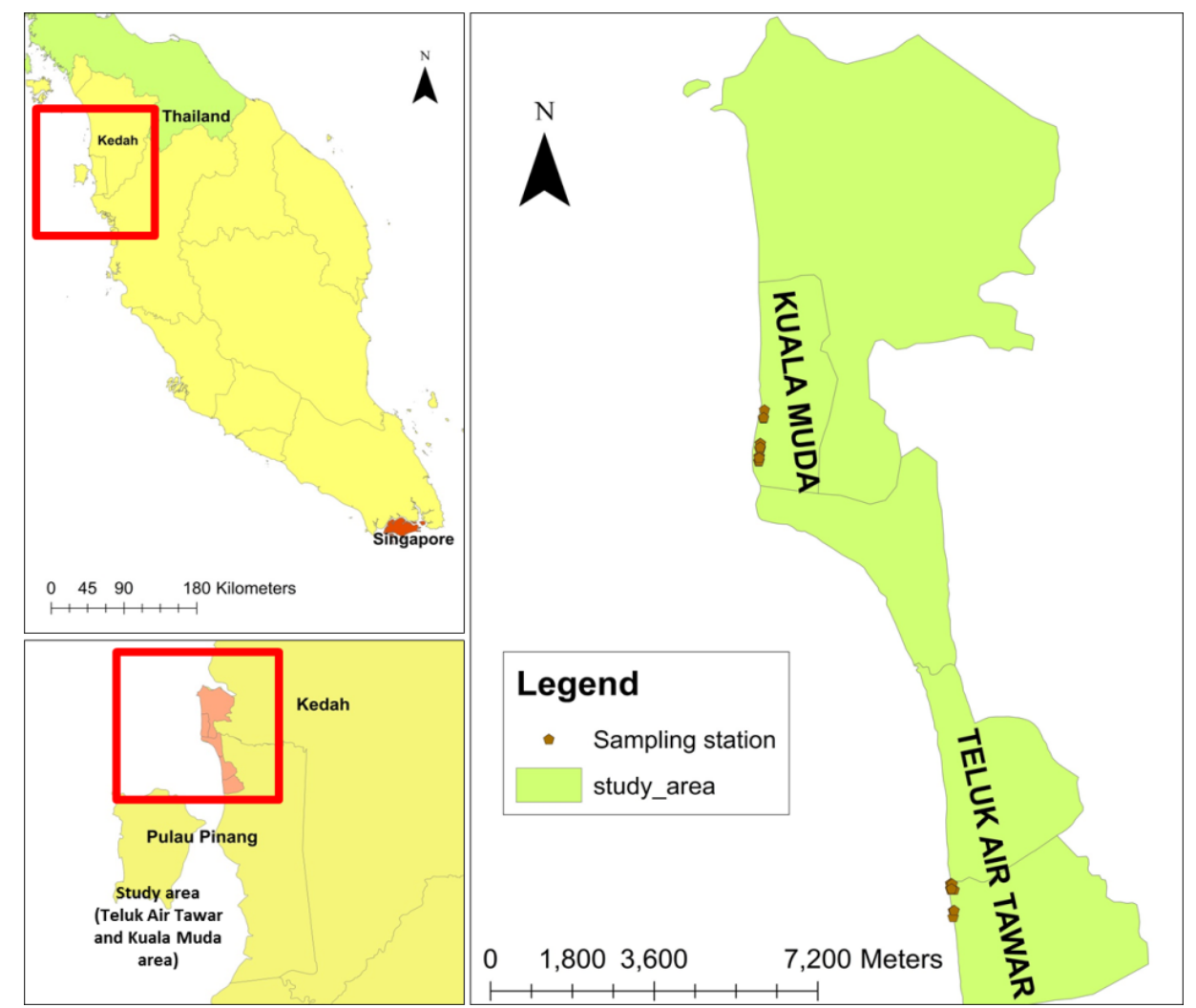

Figure 01. Teluk Air Tawar and Kota Kuala Muda Map

This seaside town has a scenic view of George Town, Penang and Penang Island across the sea while Kuala Muda is the second largest and most populous district in Kedah and it is also the site of some of the earliest civilization site in the country. The similarity is that Teluk Air Tawar and Kuala also has been acknowledged as one of the best mangrove area in Malaysia. The sampling sites were divided into six sampling sites. In Teluk Air Tawar there were three sampling sites, and same with Kuala Muda there were three sampling sites.

\subsection{Field Sampling}

The monitoring of shorebirds in Teluk Air Tawar and Kuala Muda studied by point count observation and was normally conducted on foot to easily cover the mangrove area. Only on the last day of sampling a boat is used to move along the sea which covered the whole mangrove plants and spotted many 
shorebirds. The observation was aided by using a binocular and bird watching spotting scope. Observer walked slowly not to disturb the shorebirds feeding on food in the mudflats of the mangrove area or else they will fly away.

The observation was conducted early in the morning during low tides because at that time the shorebirds will come to the mudflats for food since the water level is low. Meanwhile, the numbers of shorebirds were counted and recorded. As the water rises, the counting process continues as there were different types of shorebirds that catch fish in the water; whilst some only hunted for food inside the moist soil of the mangrove. The data that were collected and used in this research included. The shorebirds data, land used and land cover. The data had been collected throughout six sampling activities from November 2017 to January 2018 (Table 01).

Table 01. Date of sampling during data collection

\begin{tabular}{|c|l|}
\hline Sampling & \multicolumn{1}{|c|}{ Date } \\
\hline 1 & 11th November 2017 \\
\hline 2 & 25th November 2017 \\
\hline 3 & 17th December 2017 \\
\hline 4 & 14th January 2018 \\
\hline 5 & 20th January 2018 \\
\hline 6 & 30th January 2018 \\
\hline
\end{tabular}

During field sampling, binocular and spotting scope Model KOWA TSN-883 were used to spot and identify the shorebirds species. Spotting scope was needed to confirm the identification of bird with its broad optical magnification for birding. The time taken at each sub-sample to observe the shorebirds was about45 minutes to 1 hour. Besides, tide also plays a very important role in conducting this sampling. Referring to tide chart for each date of sampling was compulsory to ease the work.

\subsection{Data Analysis}

IBM SPSS Statistics 24 software was used to analyse the biotic data (the number of individual of shorebird). Biotic data was analysed by using independent $t$-test (parametric test). This research also used EstimateS 9.1.0, to identify the maximum number of sample species at Teluk Air Tawar and Kota Kuala Muda throughout the three months sampling process. In addition, Venn web tool been used to summarize the number of shorebirds species found in both sampling areas and to know the intersection of species within the three months of each sampling area. Lastly, species-richness graph was constructed to show the abundance of shorebirds and the richness of species.

\section{Findings}

\subsection{Population distribution}

Please replace this text with context of your paper. Throughout the three months period of sampling, 3293 birds were recorded in both Kota Kuala Muda and Teluk Air Tawar. There were twenty seven species from five families were accounted in the mangrove area during the survey period. In Teluk Air Tawar, 85\% 
of Scolopacidae family were recorded, followed by Ardeidae (9\%) and Charadriidae (5\%). The least abundant of shorebirds in this area is from Laridae family (1\%). While at Kota Kuala Muda, Scolopacidae family also recorded as highest family abundance, $61 \%$ of this family shorebird had been recorded from this sampling. Then followed by Charadriidae family (23\%) and Ardeidae (11\%). Laridae family also recorded as least abundant for shorebird family in Kuala Muda $5 \%$ of this bird family were recorded in this area (Figure 02).
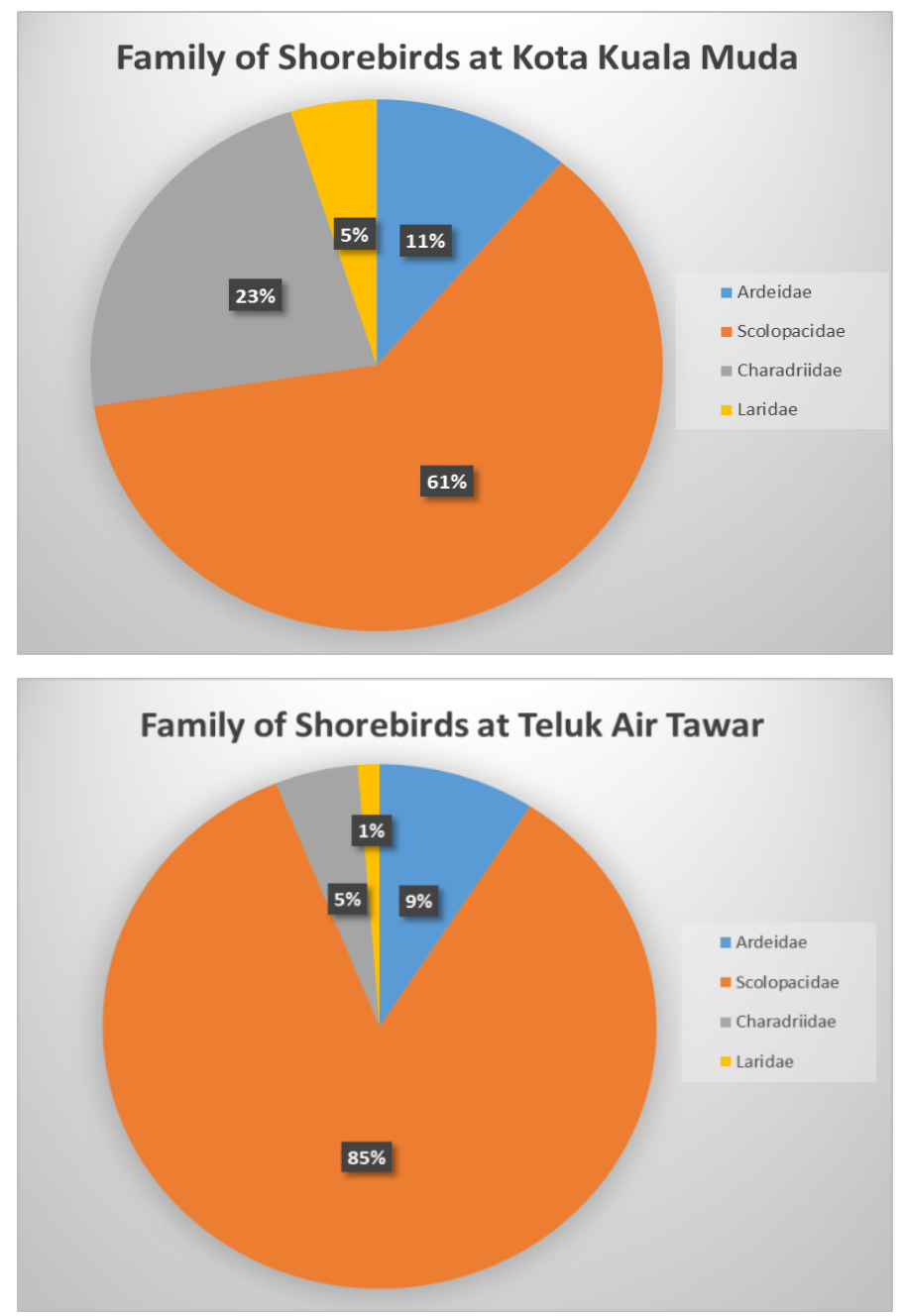

Figure 02. Family of shorebirds at Kuala Muda and Teluk Air Tawar

Scolopacidae, as exemplified by Whimbrel Numenius phaeopus, Little Heron Butorides striata and Great Egret Ardea alba mainly fed on various aquatic animals, such as small fishes, invertebrates, amphibians and crustaceans that are variety at the mangrove area. The four largest bird families were Scolopacidae (thirteen species), Ardeidae (five species), Laridae (six species), Charadriidae (three species).

Common redshank Tringa totanus and Bar-tailed godwit Limosa lapponica were among the main species observed in large numbers with the highest record of individuals of 697 and 309 throughout all samplings. Red-necked stint Calidris ruficollis and Terrek sandpiper Xenus cinereus were also observed abundantly in the mangrove area with the highest record of 306 individuals and 173 individuals, respectively. 


\subsection{Bird Abundance and Species Richness}

From Figure 03, on 11 November 2017, on the first sampling date the highest abundance of shorebirds is 324 with species-richness of 14 . On 25 November 2017, on the second sampling, the abundance of shorebirds is 171 with species-richness of 8 . Next, on the third sampling on 17 December 2017, the abundance is 274 with species-richness of 13. For the fourth sampling on 14 January 2018, the abundance is 323 with species-richness of 11 . On the fifth sampling on 20 January 2018, the abundance of shorebirds is 196 followed by species-richness of 12. On the last day of sampling on 30 January 2018, the abundance of shorebirds is 164 and the species-richness is 11.

\section{Bird abundance and species richness graph at Kota Kuala Muda}

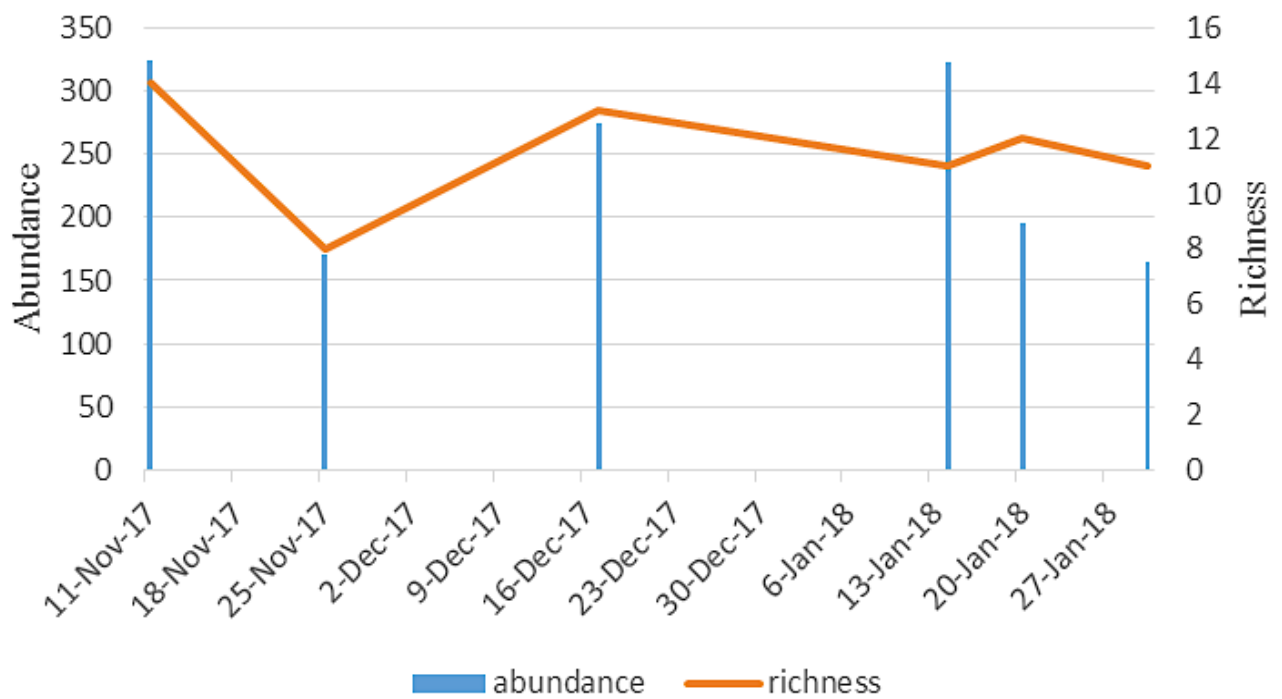

Figure 03. Bird abundance and species richness graph at Kota Kuala Muda

In November 2017, Common redshank Tringa totanus and Stint sp. were the most abundant species with the highest record of 280 individuals and 159 individuals respectively followed by December in which Common redshank Tringa totanus with 213 individuals and 133 individuals respectively. In January 2018, Red-necked stint Calidris ruficollis was recorded highest in number with 230 individuals and Stint sp. of 266 individuals. The overall abundance of shorebirds in the mangrove area at Teluk Air Tawar and Kota Kuala Muda is 1841 and 1452 respectively.

Teluk Air Tawar was identified as an ideal habitat for several bird species as it provides a mangrove estuary which functioned as a breeding site of many aquatic organisms and also shelter for various kinds of birds. For example, the Embley River, Gulf of Carpentaria, Australia, the largest catches of the commercially important banana prawns Penaeus merguiensis; were made on mangrove-lined, steeply sloping mud banks (Vance et al., 1990). Thus, mangrove estuary plays an important role to attract the many shorebird species to visit and forage for food in the mudflats. As for the mangrove area in Kota Kuala Muda, the mudflat is not as vast as the mudflat in Teluk Air Tawar. Furthermore, the mangrove forest too is not as large as Teluk Air Tawar, thus the distribution of shorebirds In Kota Kuala Muda found to be lower than shorebirds in Teluk Air Tawar. 
Bird abundance and species richness graph at Teluk Air Tawar

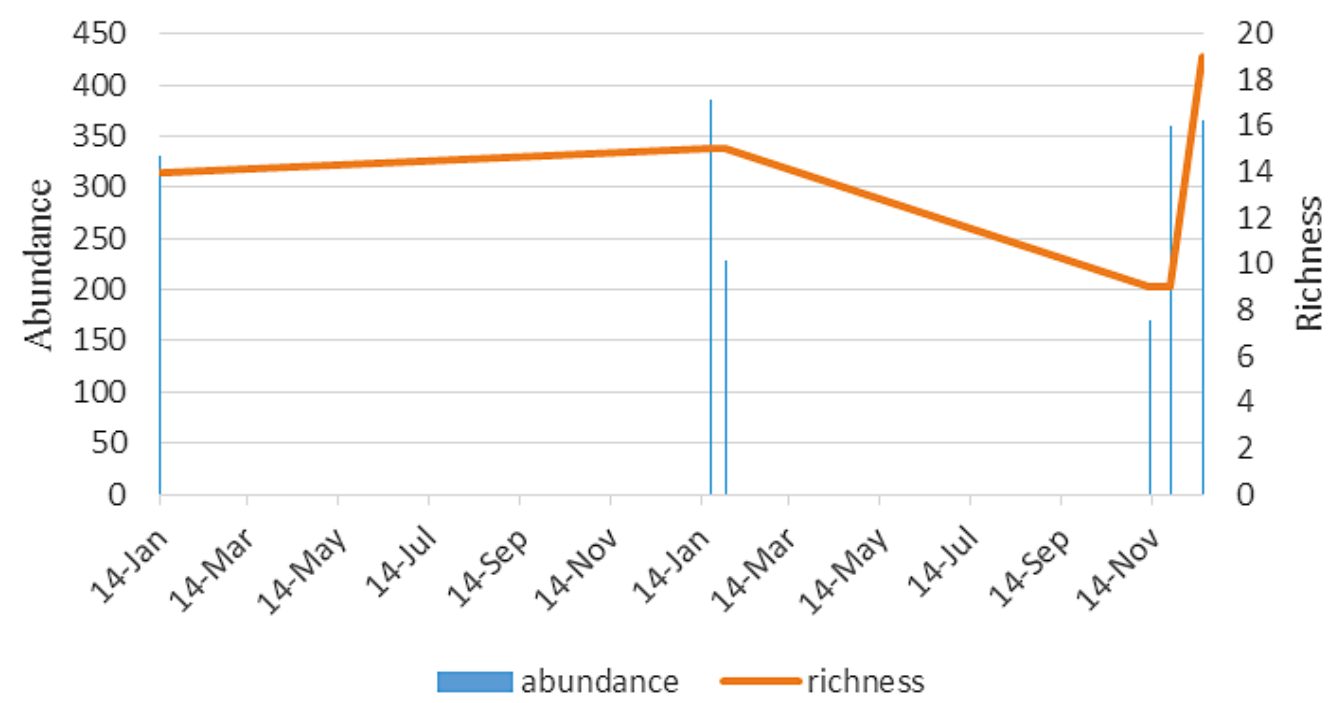

Figure 04. Bird abundance and species richness graph at Teluk Air Tawar

From figure 04, on 11 November 2017, on the first sampling date, the abundance of shorebirds was 170 with species-richness of 9 . On 25 November 2017, on the second sampling, the abundance of shorebirds is 359 with species-richness of 9. Next, on the third sampling on 17 December 2017, the abundance is 366 with species-richness of 19 . For the fourth sampling on 14 January 2018, the abundance is 331 with speciesrichness of 14. On the fifth sampling on 20 January 2018, the abundance of shorebirds is at the highest abundance of 386 followed by species-richness of 15. On the last day of sampling on 30 January 2018, the abundance of shorebirds is 229 and the species-richness is 15 .

By the end of three months sampling period, no additional species was recorded in the mangrove area. The aggregate total of species recorded remained constant at 27 species. Figure 03 and Figure 04 show the temporal variation of bird's abundance and richness in both mangrove area from November 2017 to January 2018. Distinct variation in abundance and richness of birds can be seen in the mangrove area. The birds' occurrence was highly affected by migratory seasons and the vegetation of mangrove area. During migratory seasons, more bird species can be observed due to the presence of migrant bird.

Table 02 show the types of shorebird species that visited the mangrove areas during the three months period and was illustrated using Venn diagram (Figure 05). The shorebird species been grouped in their presence month during study period.

Table 02. Venn table of shorebirds species number at Kota Kuala Muda

\begin{tabular}{|c|c|c|}
\hline Month & Total & Species \\
\hline & & Whimbrel \\
December & & Great egret \\
January & 9 & Greater sand plover \\
November & & Terrek sandpiper \\
& & Pacific golden plover Common \\
& & redshank \\
\hline
\end{tabular}




\begin{tabular}{|c|c|c|}
\hline & & $\begin{array}{c}\text { Eurasian curlew } \\
\text { Little egret } \\
\text { Common greenshank }\end{array}$ \\
\hline $\begin{array}{c}\text { December } \\
\text { November }\end{array}$ & 1 & Brown-headed gull \\
\hline $\begin{array}{c}\text { January } \\
\text { November }\end{array}$ & 2 & $\begin{array}{c}\text { Lesser sand plover } \\
\text { Common sandpiper }\end{array}$ \\
\hline $\begin{array}{c}\text { December } \\
\text { January }\end{array}$ & 2 & $\begin{array}{c}\text { Little tern } \\
\text { Pond heron }\end{array}$ \\
\hline November & 4 & $\begin{array}{c}\text { Curlew sandpiper } \\
\text { Common tern } \\
\text { White-winged tern } \\
\text { Red-necked stint }\end{array}$ \\
\hline December & 1 & Bar-tailed godwit \\
\hline January & 2 & $\begin{array}{l}\text { Little heron } \\
\text { Grey heron }\end{array}$ \\
\hline
\end{tabular}

Table 03. Venn table of shorebirds species number at Teluk Air Tawar

\begin{tabular}{|c|c|c|}
\hline Month & Total & Species \\
\hline $\begin{array}{l}\text { December } \\
\text { January } \\
\text { November }\end{array}$ & 9 & $\begin{array}{c}\text { Little tern } \\
\text { Great egret } \\
\text { Greater sand plover } \\
\text { Terrek sandpiper } \\
\text { Common sandpiper } \\
\text { Common redshank } \\
\text { Eurasian curlew } \\
\text { Little egret } \\
\text { Red-necked stint }\end{array}$ \\
\hline $\begin{array}{l}\text { December } \\
\text { November }\end{array}$ & 3 & $\begin{array}{c}\text { Broad-billed sandpiper } \\
\text { Bar-tailed godwit } \\
\text { Grey heron }\end{array}$ \\
\hline $\begin{array}{c}\text { January } \\
\text { November }\end{array}$ & 2 & $\begin{array}{l}\text { Lesser sand plover } \\
\text { Curlew sandpiper }\end{array}$ \\
\hline $\begin{array}{l}\text { December } \\
\text { January }\end{array}$ & 5 & $\begin{array}{c}\text { Whimbrel } \\
\text { Great knot } \\
\text { Pond heron } \\
\text { Whiskered tern } \\
\text { Common greenshank }\end{array}$ \\
\hline November & 1 & Asian dowitcher \\
\hline December & 2 & $\begin{array}{l}\text { Brown-headed gull } \\
\text { Marsh sandpiper }\end{array}$ \\
\hline January & 3 & $\begin{array}{c}\text { Little heron } \\
\text { Pacific golden plover } \\
\text { Bar-tailed godwit }\end{array}$ \\
\hline
\end{tabular}



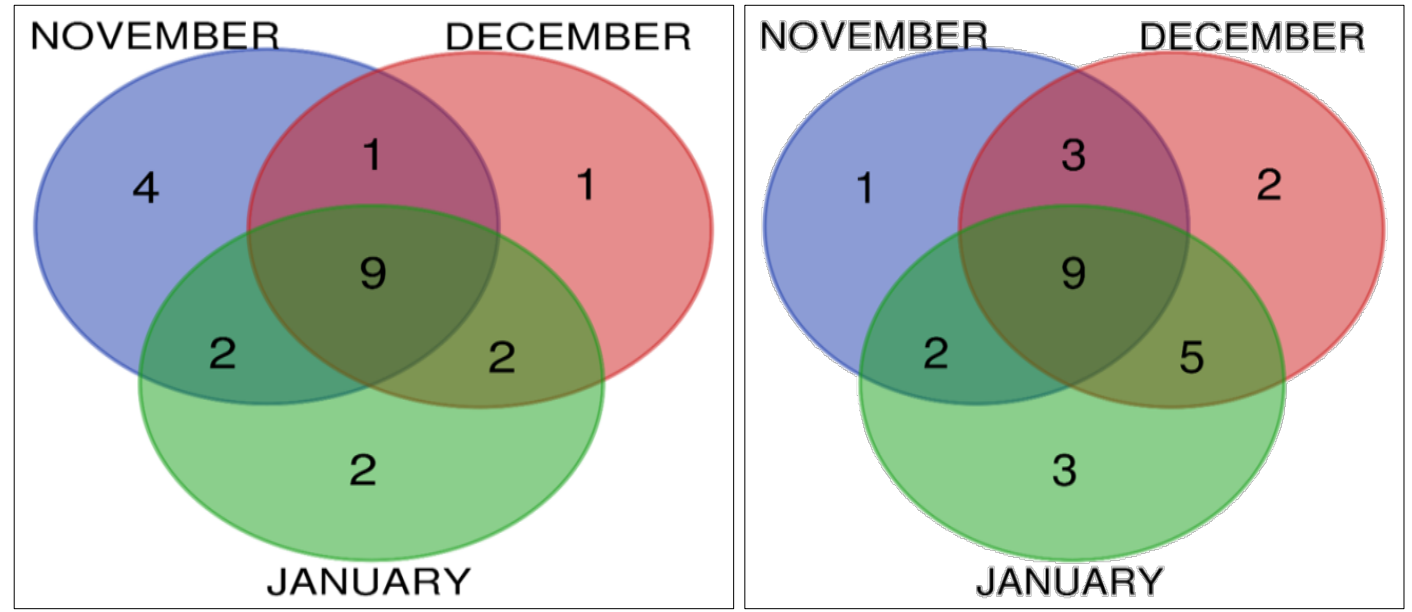

Figure 05. Bird abundance and species richness graph at Teluk Air Tawar

This study had recorded large numbers of migrant and resident birds assembled in the sampling sites during the migratory periods. This had resulted in seasonal variation of the shorebird's abundance. In December and January, shorebird abundance was at peak due to the presence of migratory shorebird during the periods while in January, of migrant species had started to reduce in numbers as they were starting to breed and return to their breeding grounds. The assemblages of big flocks of migrant birds in the sampling sites also show significant effect on resident birds. The presence of migrant species was observed to displace members of resident bird species. Although resident birds were presence throughout the study periods, the decreased in population size was observed during migratory season. These happened maybe due to competition between resident and migrant species (see Table 3).

\subsection{IUCN Status}

Pie chart had shown the IUCN Red list 2018 ver. 2 shorebird species number at both sampling sites of Kota Kuala Muda and Teluk Air Tawar.

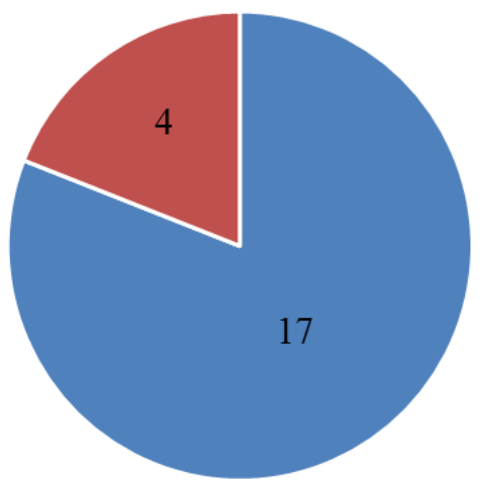

- Least Concern $\quad$ Near Threatened

Figure 06. IUCN status of shorebird species number at Kota Kuala Muda 
Based on the pie chart in Figure 06, in Kota Kuala Muda site, four (19\%) near-threatened species and $17(81 \%)$ species are in least-concern IUCN statuses were assessed.

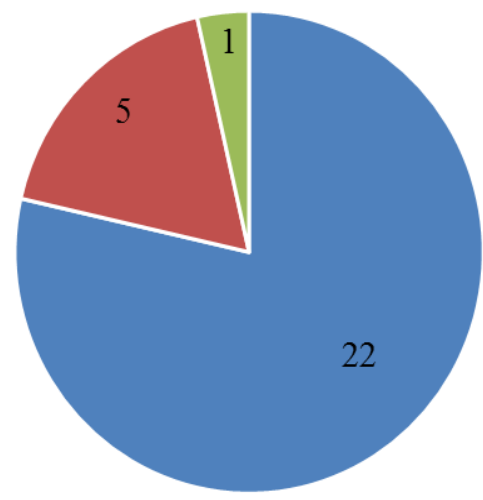

- Least Concern $\approx$ Near Threatened $\approx$ Endangered

Figure 07. IUCN status of shorebird species number at Teluk Air Tawar

Based on the pie chart in Figure 07, this project discovered one (4\%) endangered species, the Great Knot (Calidris tenuirostris), five (18\%) near-threatened species and $22(78 \%)$ least concern shorebird species at Teluk Air Tawar, according to IUCN Red List of Threatened Species.

\subsection{Assessment on species limit}

Species accumulation curve illustrated at Kota Kuala Muda and Teluk Air Tawar to show that the maximum level of shorebirds species that came to both sampling sampling during sampling activity being done.

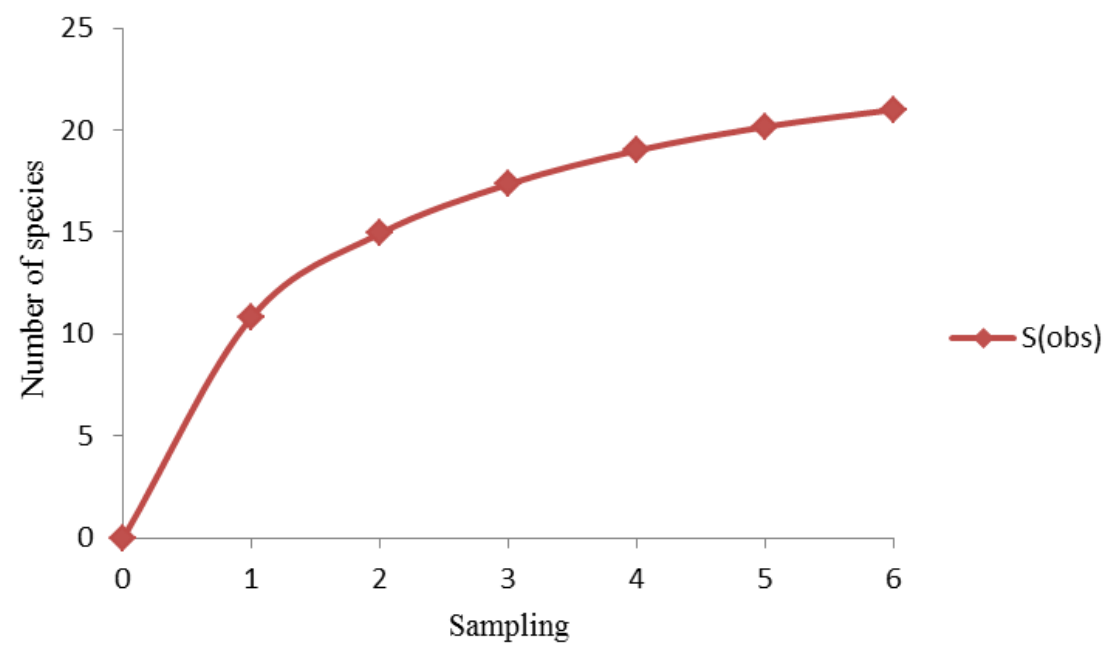

Figure 08. Species accumulation curve at Kota Kuala Muda

Based on Figure 08, for the overall six sampling activities in Kota Kuala Muda, the shorebirds species, $\mathrm{S}(\mathrm{obs})$ had been increasing gradually in numbers. At the end of sampling period, the number of 
additional species started to be constant and it is expected to meet asymptote. Thus, this sampling is hypothesized to be sufficient in which the number of species found predicted to be at maximum level.

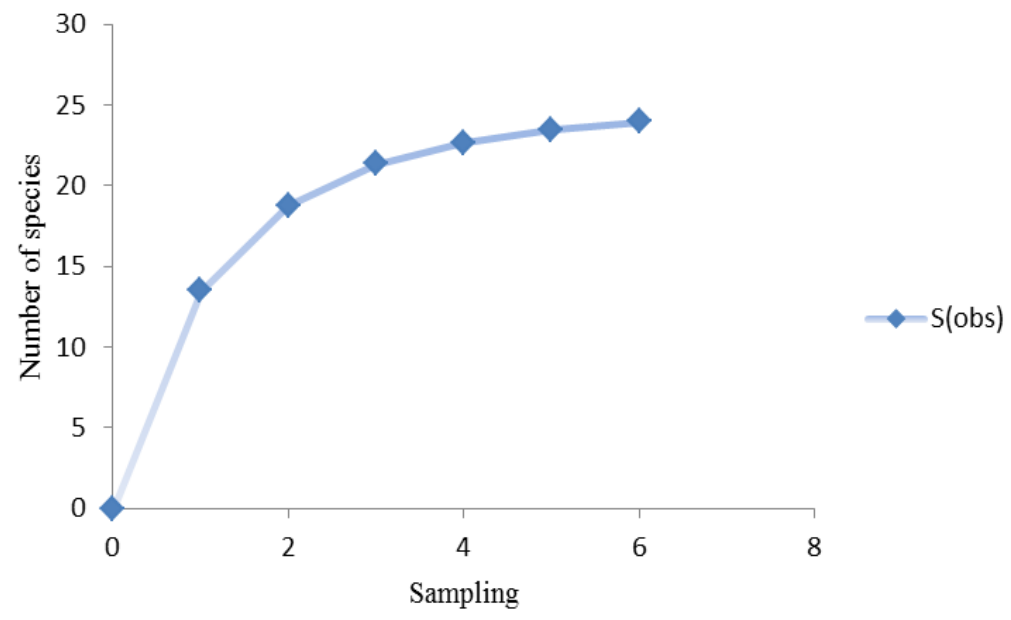

Figure 09. Species accumulation curve at Teluk Air Tawar

Based on Figure 09, for the overall of six sampling activities in Teluk Air Tawar, the shorebirds species, $\mathrm{S}(\mathrm{obs})$ had been increasing gradually in numbers. At the end of sampling, the number of additional species had started to be constant and it is expected to meet asymptote. Thus, this sampling is said to be enough in which the number of species found predicted to be at the maximum level.

Below is the table for density data that is used to be analyzed in GIS software to recognize the hotspot area of shorebirds. Thirty-six sampling sites is three sampling points at each of Teluk Air Tawar and Kota Kuala Muda for six day of sampling process been done (see Table 4).

Table 04. Density data for Geographic Information System software (GIS)

\begin{tabular}{|c|c|c|c|c|}
\hline Sampling site & $\mathbf{x}$ & $\mathbf{y}$ & Description & Density \\
\hline $\mathbf{1}$ & 100.378 & 5.491 & Teluk Air Tawar & 15 \\
\hline $\mathbf{2}$ & 100.378 & 5.496 & Teluk Air Tawar & 31 \\
\hline $\mathbf{3}$ & 100.377 & 5.496 & Teluk Air Tawar & 124 \\
\hline $\mathbf{4}$ & 100.339 & 5.582 & Kota Kuala Muda & 31 \\
\hline $\mathbf{5}$ & 100.339 & 5.582 & Kota Kuala Muda & 45 \\
\hline $\mathbf{6}$ & 100.340 & 5.582 & Kota Kuala Muda & 89 \\
\hline $\mathbf{7}$ & 100.340 & 5.497 & Teluk Air Tawar & 244 \\
\hline $\mathbf{8}$ & 100.377 & 5.496 & Teluk Air Tawar & 27 \\
\hline $\mathbf{9}$ & 100.377 & 5.496 & Teluk Air Tawar & 88 \\
\hline $\mathbf{1 0}$ & 100.339 & 5.582 & Kota Kuala Muda & 18 \\
\hline $\mathbf{1 1}$ & 100.339 & 5.586 & Kota Kuala Muda & 20 \\
\hline $\mathbf{1 2}$ & 100.340 & 5.591 & Kota Kuala Muda & 53 \\
\hline $\mathbf{1 3}$ & 100.377 & 5.497 & Teluk Air Tawar & 94 \\
\hline $\mathbf{1 4}$ & 100.377 & 5.496 & Teluk Air Tawar & 175 \\
\hline
\end{tabular}




\begin{tabular}{|c|c|c|c|c|}
\hline 15 & 100.378 & 5.496 & Teluk Air Tawar & 97 \\
\hline 16 & 100.339 & 5.583 & Kota Kuala Muda & 56 \\
\hline 17 & 100.339 & 5.586 & Kota Kuala Muda & 29 \\
\hline 18 & 100.339 & 5.591 & Kota Kuala Muda & 54 \\
\hline 19 & 100.377 & 5.497 & Teluk Air Tawar & 212 \\
\hline 20 & 100.37 & 5.496 & Teluk Air Tawar & 121 \\
\hline 21 & 100.377 & 5.491 & Teluk Air Tawar & 2 \\
\hline 22 & 100.338 & 5.583 & Kota Kuala Muda & 46 \\
\hline 23 & 100.339 & 5.584 & Kota Kuala Muda & 6 \\
\hline 24 & 100.339 & 5.592 & Kota Kuala Muda & 112 \\
\hline 25 & 100.377 & 5.496 & Teluk Air Tawar & 200 \\
\hline 26 & 100.377 & 5.496 & Teluk Air Tawar & 114 \\
\hline 27 & 100.377 & 5.490 & Teluk Air Tawar & 72 \\
\hline 28 & 100.339 & 5.583 & Kota Kuala Muda & 17 \\
\hline 29 & 100.339 & 5.585 & Kota Kuala Muda & 13 \\
\hline 30 & 100.339 & 5.591 & Kota Kuala Muda & 71 \\
\hline 31 & 100.377 & 5.497 & Teluk Air Tawar & 119 \\
\hline 32 & 100.377 & 5.496 & Teluk Air Tawar & 111 \\
\hline
\end{tabular}

\section{Conclusion}

The trend in bird migration throughout the world showed that the population of this bird species is getting decrease day by day. In Malaysia, many areas were identified as the stop-over locations for the migratory avian included Teluk Air Tawar and Kota Kuala Muda. Shorebirds species in both areas have been identified in endangered and nearly threatened status based on IUCN Red List of Threatened Species, for example Great Knot, Red-necked stint and Curlew sandpiper.

Research observations from November 2017 to January 2018 have shown that the shorebird populations in Teluk Air Tawar is higher than Kuala Muda due to its environmental factors such as near to estuary, huge intertidal mudflats and large mangrove forest in comparison to Kuala Muda that has sandy, rocky coast and less muddy area. GIS application approach was used in identifying pattern of the shorebirds and it relationship with abiotic factors at study areas. GIS using mapping system to determine hot spot habitat for shorebird species for both study areas. Mapping can explain the analysis result in visual form that much easier to understand.

This research finding helps in monitoring the distribution of shorebirds populations distribution in Teluk Air Tawar and Kota Kuala Muda coast to get clear picture of shorebird distribution in both sites. This research also shows the importance of mangrove area for shorebird species especially for foraging and resting area. The research on shorebirds in Malaysia is limited and understudied, thus this research paper will contribute towards a proper report on the important sites and the current conservation status of this particular bird species in the northern parts of Peninsular Malaysia.

Conservation program should be taken seriously by the authorities, naturalists, local people in order to highlight the importance of mangrove area as potential habitat for many shorebirds species. The main 
aim of this conservation program is to maintain the quality of mangrove area as shorebirds natural habitat.

The awareness campaigns, conservation efforts and strict regulations need to be implemented to develop sustainable ecosystem that is beneficial to both humans and wildlife communities.

\section{References}

Atkinson, P. W., Austin, G. E., Rehfisch, M. M., Baker, H., Cranswick, P., Kershaw, M., Robinson, J., Langston, R. H. W., Stroud, D. A., Turnhoutef, C. V., \& Maclean, I. M. (2006). Identifying declines in waterbirds: the effects of missing data, population variability and count period on the interpretation of long-term survey data. Biological Conservation,130(4), 549-559. https://doi.org/10.1016/j.biocon.2006.01.018

Bamford, M., Watkins, D., Bancroft, W., Tischler, G., \& Wahl, J. (2008). Migratory shorebirds of the East Asian-Australasian flyway: Population estimates and internationally important sites. Canberra: Wetlands International, Oceania.

Bart, J. (2005). Monitoring the abundance of bird populations. The Auk, 122(1), 15-25. https://doi.org/10.1093/auk/122.1.15

Dahdouh-Guebas, F., Mathenge, C., Kairo, J. G., \& Koedam, N. (2000). Utilization of mangrove wood products around Mida Creek (Kenya) amongst subsistence and commercial users. Economic Botany, 54(4), 513-527. https://doi.org/10.1007/BF02866549

Jasmi, A. (1983). Management of Taman Negara (National Park) West Malaysia. In Symposium on Wildlife Ecology in Southeast Asia. Biotrop Special Publication, Bogor, Indonesia.

Kendall, S. T. E. V. E., Payer, D. A. V. I. D., Brown, S. T. E. P. H. E. N., \& Churchwell, R. (2011). Impacts of climate change and development on shorebirds of the Arctic National Wildlife Refuge. Gyrfalcons and ptarmigan in a changing world. Boise, Idaho: The Peregrine Fund.

Kokwaro, J. O. (1985). The distribution and economic importance of the mangrove forests of Kenya.

MacArthur, R. H. (1964). Environmental factors affecting bird species diversity. The American Naturalist, 98(903), 387-397.

Rajpar, M. N., \& Zakaria, M. (2014). Mangrove fauna of Asia. In Mangrove Ecosystems of Asia (pp. 153197). Springer.

Robertson, D., \& Massenbauer, T. (2005). Applying hydrological thresholds to wetland management for waterbirds, using bathymetric surveys and GIS. In MODSIM 2005 International Congress on Modelling and Simulation (pp. 2407-2413).

Saenger, P., Hegerl, E. J., \& Davie, J. D. (Eds.). (1983). Global status of mangrove ecosystems (No. 3). International Union for Conservation of Nature and Natural Resources.

Sandilyan, S., \& Kathiresan, K. (2012). Mangrove conservation: a global perspective. Biodiversity and Conservation, 21(14), 3523-3542. https://doi.org/10.1007/s10531-012-0388-x

Vance, D. J., Haywood, M. D. E., \& Staples, D. J. (1990). Use of a mangrove estuary as a nursery area by postlarval and juvenile banana prawns, Penaeus merguiensis de Man, in northern Australia. Estuarine, Coastal and Shelf Science, 31(5), 689-701. https://doi.org/10.1016/02727714(90)90020-R

Watkins, D., \& Mundkur, T. (1997). Developing an action plan for the conservation of migratory shorebirds in the Asia-Pacific. Shorebird Conservation in the Asia-Pacific Region, Australian Wader Studies Group of Birds Australia, Hawthorn, Victoria, 76-9.

Webb, J. E., Wallwork, J. A., \& Elgood, J. H. (1979). Shore Birds. In Guide to Living Birds (pp. 78-99). Palgrave.

Wei, D. L. Z., \& Ounsted, R. (2007). The Status of Coastal Waterbirds and Wetlands in Southeast Asia.

Zakaria, M., \& Rajpar, M. N. (2010). Bird species composition and feeding guilds based on point count and mist netting methods at the Paya Indah Wetland Reserve, Peninsular Malaysia. Tropical life sciences research, 21(2), 7. 